\title{
DARWIN, WALLACE AND LINN/EUS CELEBRATIONS IN SINGAPORE
}

\begin{abstract}
CONGRESS was held in Singapore during December 2-9 to celebrate "the Centenary of the formulation of the theory of Evolution by Charles Darwin and Alfred Russel Wallace and the Bicentenary of the publication of the tenth edition of the 'Systema Naturæ' by Linnæus'.

It was particularly fitting that this Congress should have been held in Singapore for, although it honoured equally the works of Linnæus, Charles Darwin and Alfred Russel Wallace, it directed special attention to the work of Wallace, who was one of the greatest biologists ever to have worked in south-east Asia. Although it was inspired and run by a small body of organizers without any form of public recognition, and although it was financed solely by response to personal appeals, the Congress achieved international status and standards. Much credit goes to the organizers, the sponsors, and all who participated.
\end{abstract}

Twenty-three scientists visited Malaya to participate in the Congress, from Britain, Holland, India, Ceylon, Thailand, Sarawak, Hong Kong, Formosa, Australia, Hawaii, Korea and the United States. These joined with Malayan and Singaporean scientists to form a group of some sixty persons who contributed scientific papers, exhibitions, evening discourses and film shows, and attended excursions into primary forest and mangrove swamps.

Nearly six hundred members were enrolled, and attendances at meetings were consistently high. The papers delivered were of high quality and, due to good chairmanship, the meetings kept to the time programme, and adequate time was available for some stimulating discussions.

The Chief Minister of Singapore, Tun Lim Yew Hock, welcomed the visiting scientists and members of the Congress at an inaugural ceremony, which was held at King Edward VII Hall. Prof. J. B. S. Haldane (Calcutta) was then installed as president of the Congress by the vice-chancellor of the University of Malaya, Dr. A. Oppenheim. Prof. Haldane then delivered his presidential address- "The Theory of Natural Selection To-day"-to a large and colourful gathering of members and distinguished guests. The president emphasized the stimuli gained by Linnæus, Darwin and Wallace through working in peripheral areas where lack of knowledge was a challenge. $\mathrm{He}$ suggested that the next major biological advance may well come for similar reasons from peripheral places such as Singapore, or Calcutta, where this challenge still remains and where the lack of complex scientific apparatus drives biologists into different and long-neglected fields of research [see p. 710 of this issue of Nature].

The first scientific session constituted a general introduction to the Indo-Malayan Region. R. Ho (Malaya) reviewed the geological history and present geographical features of the region; E. J. H. Corner (Britain), official representative of the Royal Society, directed attention to the need for work on the rain forests of Malaysia before it was too late, and illustrated the inadequacy of our present knowledge of the area by a series of fundamental questions that remain unanswered as yet. Tom Harrisson (Sarawak) proceeded to review the changes that have occurred in Sarawak since Wallace's time, some of which were attributable to Wallace himself. such as the regrettable decimation of the orang-utan.

The papers presented in the section on evolution reflected the broad spectrum of modern non-experimental evolutionary studies. The phylogeny of fishes was considered by A. Fraser-Brunner (Singapore), of lamellibranchs by R. D. Purchon (Singapore), and of the agnathan head by R. Strahan (Hong Kong). Problems of comparative anatomy were dealt with by D. D. Davis (Chicago) and D. Barker (Hong Kong). Zoogeography was represented by a paper by J. L. Gressitt (Honolulu), Perhaps most significant was the strong emphasis on the operation of evolutionary mechanisms within small natural populations, representing promising attempts to document from Nature the mathematical models of Fisher and Wright and the laboratory experiments of Dobzhansky and others. Of a total of nine papers, three-by G. S. Carter (England), H. G. Andrewartha (Australia) and W. S. S. Van Benthem Jutting (Holland)-were concerned with one aspect or another of this important problem.

The session on parasitology and entomology opened with a review by A. A. Sandosham (Singapore) of the evolution of the parasitic mode of life. $R$. Hoeppli (Singapore) gave an entertaining review of the growth of knowledge of tapeworms, illustrating the value of the sadly neglected historical approach. J. R. Audy (Malaya) discussed evolution of parasitism in trombiculid mites; W. W. Macdonald (Malaya) reviewed the distribution and some evolutionary aspects of Malayan mosquitoes with special reference to breeding places, some species being closely associated with man through adoption of man-made breeding places. This made an interesting comparison with the discussion by L. W. Quate (Honolulu) of different patterns of dispersal and of evolution in the islands of Micronesia by two families of Dipteraempids, largely airborne, and psychodids, largely dispersed by man. J. R. Audy, in a second paper, noted that many parasites are habitat-specific rather than host-specific, or depended for transfer on particular features of host-behaviour, and stressed the value of parasites as 'ecological labels' to give ecological information about their hosts. Finally, Kim Hon-Kyu (Korea) described the life-history and host relationships of a wasp parasitic on a moth which is a potential source of silk in Korea.

At the session on zoogeography, Wallace's Line was not regarded as constituting a significant frontier between two distinct faunal areas either by $J$. L. Gressitt (Honolulu), who considered the insects, or by L. G. Brongersma (Holland), who has studied the reptiles. In both cases transition was noted rather than abrupt change. H. E. McClure (Malaya) discussed the migration of birds in the Far East and indicated the known flight routes over a wide area. In the absence of any programme of ringing of birds, little is known of the distances travelled by individuals. 
Of the six papers presented on terrestrial ecology, three were concerned with particular ecological phenomena or particular animal species and the others with the broader point of view usually called 'natural history'. In the animated discussions that followed papers and occurred informally at other times, the most notable feature was a general agreement that the fauna of the tropical rain forest, because of its extreme ecological complexity, is still so poorly understood that it can best be studied from the 'natural history' point of view, for the present leaving precise quantitative studies and intensive testing of ecological principles to workers in simpler environments in other parts of the world.

The first two papers in the session on freshwater ecology, by W. S. S. van Benthem Jutting (Holland) and D. S. Johnson (Singapore), dealt with aspects of the distribution of non-marine molluses of the Mollucas and of Indo-Pacific freshwater organisms, respectively. The latter paper, which queried the validity of the concept of a separate oriental region, provoked an interesting discussion. A paper on productivity of fishponds and similar bodies of water by G. R. Fish (Malaya) elicited a lively and informative discussion. Other papers included colonization of freshwater habitats by aquatic insects by C. N. Fernando (Ceylon) and the study of breathing behaviour of salamanders and of the climbing perch by $H$. Spurway (Calcutta).

The genetics section opened with four papers on human polymorphism in South-east Asia. F. Vella (Singapore) described abnormal hæmoglobins in local Chinese, Indians, Malays and others; thalassæmia was not uncommon in Chinese and Malays, sometimes associated with abnormal hæmoglobins. I. Polunin (Singapore) discussed wide variations in blood-group frequencies in different settlements of the same aboriginal tribe, probably due to genetic drift. D. C. Rife (Bangkok) presented dermatoglyphic evidence that Thai people are closely related to Chinese, while E. McEvoy-Bowe (Singapore) described his work on $\beta$-amino-isobutyric acid excretion in local peoples and gave details of his useful new method for the accurate estimation of urinary amino-acids in chromatograms.

Among later papers, that of C. F. Hickling aroused special interest. He described hybridization experiments with important food-fish of the Tilapia mossambica group. Some crosses led to all-male $F_{1}$ progeny with marked hybrid vigour, growing about twice as fast as the parent stocks. S. K. Roy (Calcutta) described the wide polymorphism of Indian cattle and buffaloes, with special reference to nipple number. A. G. Searle (Singapore) showed that threshold characters were remarkably common in local wild mice as well as in domesticated animals. He suggested that anencephaly in humans was also due to a threshold mechanism. The last contribution, by Helen Spurway and A. Kumar (Calcutta), on variation under domestication, contained some intriguing suggestions; for example, that "we have not domesticated plants, but they have domesticated us". The chairman (J. B. S. Haldane, Calcutta), in summing up, pointed out the great opportunities in tropical countries for work on human genetics and on cultivated plants and animals in the early stages of domestication.

The section on anthropology covered a wide range of subjects. V. Thambipillai (Singapore) described the physical types of man now living in Malaya, while G. C. Whittow (Singapore) and T. S. Lee
(Singapore) both discussed physiological adaptations to life in the humid tropics. I. Polunin (Singapore) concluded that the falling birth-rate in the Muruts of North Borneo may arise chiefly from infectious disease following pregnancy. Tom Harrisson (Sarawak), drawing vividly on his own experiences, gave a stimulating review of the basic problems of living in the jungle. M. Benanzio (Singapore) commented on the high incidence of 'Mongolian spot' in certain populations in Sumatra.

The most interesting contribution in the session on systematics was perhaps the description and discussion by D. Barker (Hong Kong) of the interesting crustacean Thermosbaena mirabilis, representative of the small and often neglected order Thermosbaenacea. Further papers were presented by D. S. Johnson (Singapore), P. J. van der Feen (Holland) and L. G. Brongersma (Holland) on a variety of topics ranging from variation in freshwater prawns to the fauna of New Guinea.

E. J. H. Corner (Britain) opened the botanical session and concluded from an attempt to reconstruct the evolution of tropical broad-leaved forest that it was perfected at the beginning of the Cretaceous period before there were, apparently, modern birds and mammals such as now use it. H. B. Gilliland (Singapore) directed attention to the importance of the orchid seedling, with its changes in symmetry, to plant morphology. J. Wyatt-Smith (Malaya) suggested that the vegetation of Pulau Pangkor in the Malacca Straits was destroyed by the eruption of the Toba Lake volcano and that the new flora is of oceanic type, depending mainly on wind- or animal-dispersal of seeds. E. A. Rosenquist (Malaya) discussed the physiology and geneties of palms ; G. A. Prowse (Malaya) described new species of Flagellata which provide important sources of fish-food in the fish ponds in which several are characteristic. Yen Yo-Min (Singapore) described the discovery of six Cercospora diseases on sugar cane in Formosa. S. K. Roy (Calcutta) gave an account of variation of leaves on the same plant in Nyctanthes arbor-tristis. A. Johnson (Singapore) discussed the distribution of Malayan mosses and green seaweeds, an important extension of Malaysian phytogeography. Finally, A. Santiago (Malaya) spoke of the importance of agricultural genetics in applied botany and the shortcomings of reliance on vegetative propagation.

The week-end excursion to Bukit Timah gave a valuable introduction to Malayan rain forest for those to whom it was new, since Bukit Timah is a most important type locality for plants and animals in Malaysia. This is now a carefully protected nature reserve of some 150 acres.

An all-day excursion began with exploration of the mangrove swamp in the Pandan Nature Reserve. The party saw many interesting species, including some large mud-skippers (Periophthalmus), one of which was being killed and consumed by the common dog-faced water snake (Cerberus).

The scientists visiting Malaya were entertained at a cocktail party at the residence of the chairman of the Organizing Committee on the first evening. On subsequent evenings there was a diversity of public functions, which were particularly appreciated by the many local members who were not free earlier in the day. There were public lectures by J. B. S. Haldane (Calcutta), J. R. Hendrickson (Singapore) and by H. Munro Fox (Britain), the representative to the Congress from the British Association for the Advancement of Science. There were two evenings 
of film shows ; the first consisted of films taken in Sarawak and presented with a lively running commentary by Tom Harrisson (Sarawak), while the second included films taken in New Guinea and presented personally by L. G. Brongersma (Holland), one taken in North Borneo and presented personally by I. Polunin (Singapore), and one by the Malayan Film Unit, which was introduced by R. D. Purchon (Singapore).

The British Council prepared a photographic exhibition of Darwiniana specially for the Congress, and this was displayed in the Art Museum of the University of Malaya, where it was the object of considerable interest. The exhibition was afterwards displayed in Kuala Lumpur and, so that the maximum benefit should be gained from its preparation, it was then sent on tour; part was sent to Colombo for the meeting of the Ceylon Association for the Advancement of Science and the remainder was sent first to Kuala Lumpur and then to Bangkok. On its return it will be presented to the Department of Zoology, University of Malaya, through the generosity of the British Council.

A bibliographic exhibition was organized by the Foreign Service of the United States and consisted of about three hundred biological publications the majority of which were sent from America specially for the Congress, and the greater part of which has been most generously presented to the library of the University of Malaya. This exhibition was augmented by a smaller number of British works, loaned for the occasion by the Singapore agents of various British publishing houses.

After the Congress, an excursion lasting a fortnight was conducted which traversed the west-coast districts of Malaya as far as Perlis. Special attention was paid to freshwater habitats ; the variety observed ranging from rice-fields to torrent-streams, and from acid blackwaters to limestone pools. In addition, visits were made to the Fish Culture Research Station at Batu Berendam, Malacca (Nature, 183, 287 ; 1959); to the Rubber Research Institute and the Institute for Medical Research at Kuala Lumpur ; and to the Fisheries Department and the Bayan Lepas Experimental Farm at Penang. The opportunity was taken to visit and collect from a number of limestone hills and caves.

The post-Congressional field trip to the King George V National Park in the depths of Pahang brought together nine biologists from four continents, whose interests ranged through taxonomy, zoogeography, ecology and evolution. The base of the party was at Kuala Tahan, where they lived in a lodge of the National Park, with adjacent facilities in the Forest Research Laboratory of the Department of Zoology, University of Malaya. The party spent six days walking and collecting through a number of different types of vegetation. They inspected the pattern of quadrats laid out by the Department of Zoology as a part of its long-term programme of ecological research in the jungle. Valuable suggestions were received from the visiting scientists regarding methods of approach and priorities in this programme.

Arrangements were made for some of the visitors to lecture at Kuala Lumpur in the Federation of Malaya, to widen the impact of the Congress. Prof. J. B. S. Haldane gave the substance of his lecture on natural selection and genetics, previously delivered in Singapore, to a special meeting of the Malayan Nature Society. In addition, the Malayen Scientific Association convened a special meeting, at which $H$. Waring (Australia) discussed the studies, which he had previously presented in Singapore, on the marsupial quokka. H. G. Andrewartha (Australia) described some extremely interesting experiments on mice still in progress in Adelaide. These bear directly on intra-specific elements influencing reproduction and may help to interpret the regulation of population densities. L. G. Brongersma showed and commented on the cine film of his zoological field work in Dutch New Guinea. The visitors saw the forest reserves and the laboratories of the Institute for Medical Research and of the Rubber Research Institute.

The proceedinge of the Congress were covered by the Malayan Film Unit, and it is anticipated that a documentary film will be released in the near future.

Any credit balance remaining in the hands of the chairman of the Organizing Committee will be applied as an endowment to provide a book prize in the University of Malaya as a permanent reminder of this very successful Congress and the events which it honoured. Since the Congress was originally conceived to pay public tribute to the works of Alfred Russel Wallace in Malaysia, it is fitting that this should be known as the 'Wallace Prize'. A few copies of the abstracts of papers and of the programme are available (3s. and $2 s$, respectively, including postage).

The scientific papers will be published in full in book form. Applications for the abstracts and programme and advance orders for the scientific papers should be sent to Prof. R. D. Purchon, Department of Zoology, University of Malaya. $\quad$ R. D. PurchoN

\section{THE HAFFKINE INSTITUTE, BOMBAY DIAMOND JUBILEE}

$\mathrm{O}$ N January 10 the Haffkine Institute in Bombay celebrated sixty years of service in medical research. At the opening ceremony, which was attended by scientists from India and from other countries, the President of the Republic of India, Dr. Rajendra Prasad, said that Dr. W.M. W. Haffkine, founder of the Institute, had built up a tradition which the modern scientific world could best honour by emulation. It might have been a coincidence that a scientist born in Russia and trained in France happened to be in India, when he was assigned the urgent task of preventing plague from taking a heavy toll of lives; but, the President continued, it served to illustrate that scientific advance of all types called for international collaboration. The Bombay Health Minister, welcoming the delegates, announced that the Government of India had given Rs. 300,000 for the expansion of the Institute and that the Government of Bombay had decided to create a special fund for its development.

Waldemar Mordecai Wolff Haffkine was born of Jewish parents at Odessa on March 15, 1860. He 